\title{
PEMANFAATAN UMPAN ALTERNATIF LIMBAH KEPALA UDANG DAN WAKTU IMMERSING BUBU LIPAT TERHADAP HASIL TANGKPAAN RAJUNGAN (Portunus pelagicus) DI PERAIRAN KARIMUNJAWA KABUPATEN JEPARA
}

\section{Utilization of Alternative Shrimp Head Waste Feed and Immersing Time of Pot on the Catch of Swimming Crab (Portunus Pelagicus) in Karimunjawa Waters of Jepara District}

\author{
Martiana Neilirrohmah, Aristi Dian Purnama Fitri*), dan Sardiyatmo \\ Program Studi Pemanfaatan Sumberdaya Perikanan, Jurusan Perikanan \\ Fakultas Perikanan dan Ilmu Kelautan,Universitas Diponegoro \\ Jl. Prof. Soedarto,SH Tembalang, Semarang \\ Email : martiananeilirohmah@yahoo.com, aristidian.undip@gmail.com, aristidian@fisika.undip.ac.id
}

Diserahkan tanggal 26 Juli 2018, Diterima tanggal 22 Desember 2018

\begin{abstract}
ABSTRAK
Bubu lipat adalah alat tangkap yang digunakan untuk menangkap rajungan di Perairan Karimunjawa. Umpan yang biasa digunakan yaitu ikan segar (Damselfish), namun memiliki kendala sehingga peneliti memberikan solusi menggunakan umpan limbah kepala udang (Paneus merguensis) karena murah, bisa didapat dari limbah rumah tangga, serta mengandung protein yang dapat merangsang indera penciuman Rajungan (Portunus pelagicus). Tujuan penelitian adalah menganalisis hasil tangkapan Rajungan (Portunus pelagicus) dengan bubu lipat umpan limbah kepala udang (Penaeus merguensis) dan umpan ikan segar (Damselfish), serta perbedaan waktu immersing (6 jam dan 12 jam). Metode penelitian yang digunakan adalah experimental fishing dengan 8 kali pengulangan. Penelitian dilakukan di Perairan Karimunjawa, Kabupaten Jepara pada bulan Februari 2018. Analisis data menggunakan uji normalitas, uji homogenitas, dan uji-t. Hasil tangkapan Rajungan (Portunus pelagicus) dengan umpan limbah kepala udang lebih sedikit dibandingkan dengan umpan ikan segar (Sig. 0,538). Hasil tangkapan Rajungan (Portunus pelagicus) pada waktu immersing 6 jam lebih banyak dibandingan waktu immersing 12 jam (Sig. 0,512). Tidak terdapat interaksi antara umpan dan waktu immersing terhadap hasil tangkapan Rajungan (Portunus pelagicus) pada penangkapan bubu lipat di Karimunjawa.
\end{abstract}

Kata kunci: Karimunjawa, rajungan (Portunus pelagicus), jenis umpan, waktu immersing.

\begin{abstract}
Trap is one of the fishing gear used to catch a swimming crabs in Karimunjawa. Usually the bait is used fresh baits (Damselfish), but have constraints so the researcher giving a solution to use shrimp head waste (Penaeus merguensis) because cheap, can get from household waste, and contains protein that can stimulate the sense of swimming crabs's smell. The research purposes to analyze the ratio of the catches between pot using shrimp head waste (Penaeus merguensis) with fresh baits (Damselfish) and immersing time difference (6 hours and 12 hours). The research method used in this study was the experimental fishing with 8 times repetition. The research held at Karimunjawa waters of Jepara District on February 2018. The data analysis used were the normality test, the homogenity test and t-test. The resulted of swimming crabs on the pot with shrimp head waste is less more than fresh baits (Sig. 0,538). The resulted of swimming crabs on pot with 6 hours of immersing time is in the largest number of catch (Sig. 0,512). Fresh fish baits and shrimp head waste feed and immersing time between 6 hours and 12 hours no interaction the catch of swimming crabs in Karimunjawa.
\end{abstract}

Keywords: Karimunjawa, swimming crab (Portunus pelagicus), type of bait, immersing time.

\section{PENDAHULUAN}

Rajungan (Portunus pelagicus) merupakan kepiting laut yang banyak terdapat di Perairan Indonesia. Rajungan telah lama diminati oleh masyarakat baik di dalam negeri maupun luar negeri, oleh karena itu harganya relatif mahal yang dapat mencapai Rp.30.000-50.000/kg daging. Rajungan ini juga di ekspor ke luar negeri seperti ke Jepang, Singapura dan Amerika. Rajungan di Indonesia sampai sekarang masih merupakan komoditas perikanan yang memiliki nilai ekonomis tinggi. Sampai saat ini seluruh kebutuhan ekspor rajungan masih mengandalkan dari hasil tangkapan di laut (Pangalila dan Ivor, 2016). 
Pengoperasian bubu lipat oleh nelayan dengan bantuan umpan. Umpan merupakan salah satu faktor yang mempengaruhi keberhasilan penangkapan bubu. Umpan berperan sebagai salah satu bentuk pemikat yang memberikan rangsangan yang bersifat fisika dan kimia. Bau-bau yang terlarut di dalam air dapat merangsang reseptor pada organ. Umpan yang digunakan untuk kegiatan penangkapan bubu adalah ikan petek mati yang masih segar. Umpan ini digunakan para nelayan bubu karena ikan petek memiliki bau yang sangat menyengat (Arios et al., 2013). Umpan yang biasa digunakan nelayan karimunjawa adalah ikan segar. Namun nelayan bubu lipat kadang masih memiliki kendala untuk mendapatkan ikan segar karena harus menangkap terlebih dahulu dari laut atau membeli ikan dari nelayan lainnya yang berarti menambah pengeluaran modal. Oleh karena itu, peneliti memberikan solusi dengan memanfaatkan limbah kepala udang yang berasal dari limbah rumah tangga. Limbah kepala udang murah dan memiliki bau yang menyengat sehingga dapat dimanfaatkan sebagai umpan. Hal yang perlu diperhatikan dalam memilih umpan adalah kebiasaan makan sasaran penangkapan, dapat memberikan rangsangan bau dan penglihatan terhadap sasaran, ukuran umpan harus disesuaikan dengan jenis sasaran, dan harga umpan harus murah dan tersedia secara terus menerus (Subani dan Barus, 1989).

Selain itu, peneliti juga melakukan penelitian terhadap lama waktu ideal perendaman bubu lipat sehingga dapat menghasilkan hasil tangkapan yang maksimal dan berkualitas baik. Biasanya nelayan bubu lipat di Karimunjawa melakukan perendaman \pm 12 jam. Untuk mengetahui waktu ideal perendaman bubu lipat, peneliti menggunakan 2 perbedaan waktu, yaitu selama 6 jam dan 12 jam sesuai dengan kebiasaan nelayan (variabel kontrol). Tujuan dari penelitian ini adalah untuk menganalisis hasil tangkapan Rajungan (Portunus pelagicus) dengan bubu lipat umpan limbah kepala udang (Penaeus merguensis) dan umpan ikan segar (Damselfish), serta perbedaan waktu immersing (6 jam dan 12 jam).

\section{METODE PENELITIAN}

Penelitian ini dilaksanakan pada bulan Februari 2018 yang bertempat di Perairan Karimunjawa, Kabupaten Jepara. Objek dalam penelitian ini adalah alat tangkap bubu lipat nelayan Karimunjawa. Sedangkan subyek penelitian adalah limbah kepala udang yang dimasukkan ke dalam kantong plastik bening yang dilubangi, serta perbedaan lama waktu immersing bubu lipat. Data yang dibutuhkan adalah data primer dan data sekunder. Data primer berasal dari observasi, wawancana, studi pustaka, dan dokumentasi, sedangkan data sekunder berasal dari PPP Karimunjawa. Tahap-tahap pelaksaan penelitian adalah sebagai berikut:

a. Persiapan (Setting)

Bubu yang berjumlah 20 buah disiapkan dengan membagi menjadi 2 bagian dan dipasang secara rawai. 10 bubu menggunakan umpan ikan segar dan 10 bubu menggunakan umpan limbah kepala udang. Kedua bagian tersebut menggunakan waktu immersing yang sama dalam sekali perlakuan dan diulang 8 kali. 10 bubu tersebut disusun secara berangkai dengan 1 tali utama dan menggunakan 2 buah pelampung. Setelah persiapan selesai, kemudian menuju fishing ground dengan menggunakan perahu. Berikut ini adalah ilustrasi pemasangan bubu lipat di perairan:

b. Pemasangan

Setelah menemukan fishing ground di sekitar Selat Karimunjawa, 20 buah bubu lipat yang sudah dipasangi umpan dilempar ke perairan. Waktu setting pada pukul 17.00 WIB. Setting pada minggu pertama untuk waktu immersing 6 jam dengan umpan ikan segar dan limbah kepala udang. Karena cuaca buruk, maka waktu immersing 12 jam dengan umpan ikan segar dan limbah kepala udang dilakukan setting pada minggu selanjutnya. Hal tersebut dengan asumsi bahwa kondisi perairan sudah kembali normal setelah cuaca buruk dan kedua umpan yang digunakan dalam kondisi perlakuan yang sama seperti setting pada minggu pertama. Maka diasumsikan hasil tangkapan yang didapat sama seperti minggu pertama.

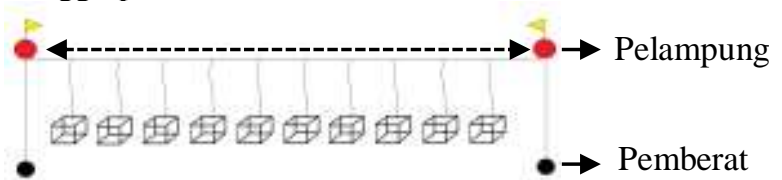

Bubu lipat umpan limbah kepala udang

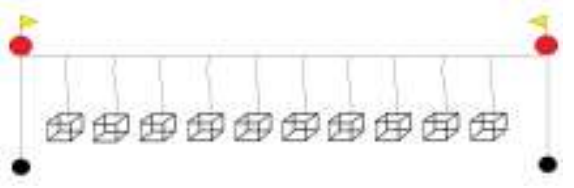

Bubu lipat umpan ikan segar

Gambar 1. Ilustrasi Pemasangan Bubu Lipat di Perairan

c. Perendaman (Immersing)

Pada penelitian ini dilakukan dua perlakuan perbedaan waktu immersing yaitu waktu immersing 6 jam dan 12 jam (kontrol).

d. Penarikan (Hauling)

Penarikan bubu lipat dengan waktu immersing 6 jam dilakukan pada pukul 22.00 WIB. Sedangkan penarikan bubu lipat dengan waktu immersing 12 jam dilakukan pada pukul 06.00 WIB.

\section{Analisis data}

Analisis data yang digunakan dalam penelitian ini adalah uji-t dengan aplikasi SPSS 22.0. Peneliti ingin mengetahui perbedaan hasil tangkapan antara bubu lipat dengan umpan kepala udang dan bubu lipat dengan umpan ikan segar, serta dengan adanya lama perendaman bubu lipat yang berbeda pada masing-masing kelompok. Sebelum menggunakan uji-t, data diolah menggunakan uji normalitas Shapiro Wilk dan uji homogenitas untuk mengetahui data bersifat normal atau tidak.

\section{Hipotesis}

Hipotesis pada penelitian ini adalah:

1. Pengaruh umpan berbeda

$\mathrm{H}_{1}$ : Terdapat pengaruh umpan limbah kepala udang dan ikan segar pada alat tangkap bubu lipat terhadap hasil tangkapan Rajungan (Portunus pelagicus) di Karimunjawa

$\mathrm{H}_{0}$ : Tidak terdapat pengaruh umpan limbah kepala udang dan ikan segar pada alat tangkap bubu lipat

(c) Copyright by Saintek Perikanan (Indonesian Journal of Fisheries Science and Technology), ISSN : 1858-4748 
terhadap hasil tangkapan Rajungan (Portunus pelagicus) di Karimunjawa

2. Pengaruh waktu immersing berbeda

$\mathrm{H}_{1}$ : Terdapat pengaruh waktu immersing selama 6 jam dan 12 jam pada alat tangkap bubu lipat terhadap hasil tangkapan Rajungan (Portunus pelagicus) di Karimunjawa

$\mathrm{H}_{0}$ : Tidak terdapat pengaruh waktu immersing selama 6 jam dan 12 jam pada alat tangkap bubu lipat terhadap hasil tangkapan Rajungan (Portunus pelagicus) di Karimunjawa

\section{HASIL DAN PEMBAHASAN}

Hasil tangkapan total pada bubu lipat selama penelitian adalah Rajungan (Portunus pelagocus), kepiting batu (Thalamita sima), udang ronggeng (Harpiosquilla raphidea), dan kerapu lumpur (Epinephelus bleekeri). Hasil tangkapan utama dari bubu lipat ini adalah Rajungan (Portunus pelagicus), dan tangkapan sampingannya yaitu kepiting batu (Thalamita sima), udang ronggeng (Harpiosquilla raphidea), dan kerapu lumpur (Epinephelus bleekeri). Komposisi hasil tangkapan pada penelitian ini dapat dilihat pada Gambar 1.

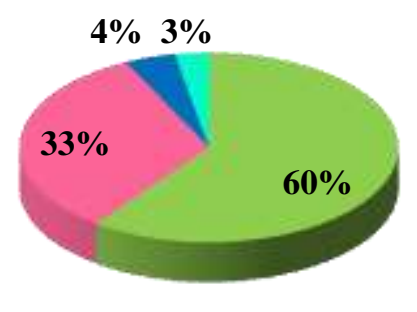

\section{Rajungan \\ Kepiting Batu \\ - Udang Ronggeng \\ - Kerapu Lumpur}

Gambar 2. Diagram Komposisi Hasil Tangkapan Bubu Lipat

Berdasarkan Gambar 2 di atas, dapat diketahui bahwa komposisi hasil tangkapan bubu lipat tertinggi adalah Rajungan (Portunus pelagicus) dengan presentase $60 \%$ dan posisi kedua adalah Kepiting Batu (Thalamita sima) dengan presentase 33\%. Udang Ronggeng (Harpiosquilla raphidea) dan Kerapu Lumpur (Epinephelus bleekeri) berturut-turut 4\% dan 3\%. Secara keseluruhan hasil tangkapan bubu lipat didominasi oleh tangkapan target catch yaitu Rajungan (Portunus pelagicus) berjumlah 83 ekor dan bycatch yaitu Kepiting Batu (Thalamita sima), Udang Ronggeng (Harpiosquilla raphidea), dan Kerapu Lumpur (Epinephelus bleekeri) berjumlah 55 ekor. Menurut Wang et al. (2010), proporsi tingginya hasil tangkapan utama (target catch) dapat membuktikan bahwa alat tangkap yang digunakan selama penelitian bersifat ramah lingkungan. Salah satu penilaian tingkat keramah lingkungan suatu alat tangkap dapat dilakukan dengan membandingkan proporsi target catch dan bycatch. Jika proporsi target catch yang diperoleh $\geq 60 \%$, maka alat tangkap tersebut dapat dikatakan ramah lingkungan.

\section{Perbandingan Hasil Tangkapan Rajungan (Portunus pelagicus) Berdasarkan Umpan Berbeda}

Jumlah hasil tangkapan Rajungan (Portunus pelagicus) pada penelitian ini secara rinci dapat dilihat dalam Gambar 3.

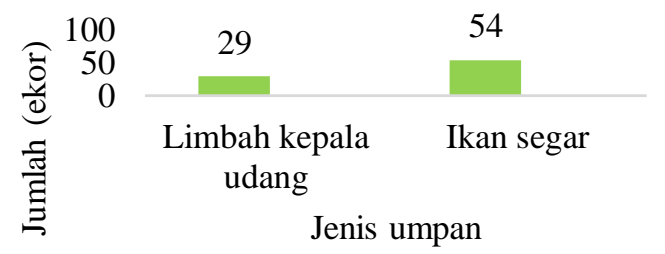

Gambar 3. Grafik Perbandingan Hasil Tangkapan Rajungan (Portunus Pelagicus) Berdasarkan Umpan Berbeda

Berdasarkan Gambar 3 di atas, menunjukkan bahwa bubu lipat dengan umpan ikan segar mendapatkan Rajungan (Portunus pelagicus) lebih banyak dibandingkan dengan umpan limbah kepala udang. Hal ini kemungkinan karena aroma ikan segar lebih menyengat sehingga Rajungan (Portunus pelagicus) lebih tertarik dengan umpan ikan segar. Hal ini diperkuat oleh Monintja dan Martasuganda (1991), terperangkapnya udang, kepiting atau ikan-ikan dasar disebabkan oleh beberapa faktor, salah satu diantaranya dikarenakan tertarik oleh bau umpan. Bau-bau yang terlarut di dalam air dapat merangsang reseptor pada organ olfaktorius yang merupakan bagian dari indera penciuman ikan atau jenis $c r a b$.

Umpan limbah kepala udang ada yang sama sekali tidak mendapatkan Rajungan (Portunus pelagicus) kemungkinan karena umpan hilang di perairan selama immersing akibat arus yang kuat setelah hujan. Hal ini serupa dengan penelitian Widowati et al. (2015), yang menyatakan bahwa perbedaan hasil tangkapan bubu lipat dengan umpan yang berbeda dipengaruhi oleh beberapa faktor, diantaranya hilangnya umpan di dalam perairan, tingkah laku dari rajungan, ketertarikan Rajungan ( $P$. pelagicus) terhadap umpan, dan lamanya waktu perendaman. Grafik perbandingan hasil tangkapan utama dan hasil tangkapan sampingan yang teratrik denganbubu lipat dapat dilihat pada Gambar 4.

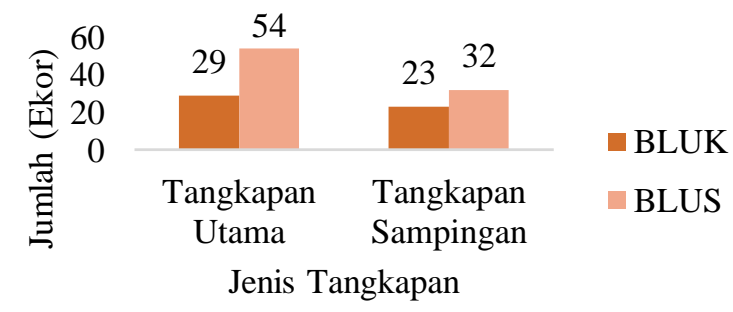

Gambar 4. Grafik Hasil Tangkapan Utama dan Hasil Tangkapan Sampingan Bubu Lipat

Keterangan :

BLUK: Bubu lipat dengan umpan limbah kepala udang;

BLUS: Bubu lipat dengan umpan ikan segar.

Berikut adalah hasil uji proksimat dari penelitian ini:

Tabel 1. Hasil Uji Proksimat

\begin{tabular}{lcccc}
\hline \multirow{2}{*}{ Umpan } & \multicolumn{4}{c}{ Uji Proksimat } \\
\cline { 2 - 5 } & $\begin{array}{c}\text { Kadar } \\
\text { protein }\end{array}$ & $\begin{array}{c}\text { Kadar } \\
\text { air }\end{array}$ & $\begin{array}{c}\text { Kadar } \\
\text { abu }\end{array}$ & $\begin{array}{c}\text { Kadar } \\
\text { lemak }\end{array}$ \\
\hline $\begin{array}{l}\text { Limbah } \\
\text { kepala }\end{array}$ & $38,60 \%$ & $73,43 \%$ & $1,77 \%$ & $2,13 \%$ \\
udang & & & & \\
Ikan segar & $57,23 \%$ & $74,79 \%$ & $1,55 \%$ & $2,63 \%$ \\
\hline Sumber: Penelitian, 2018. & & &
\end{tabular}


Ikan segar memiliki kadar protein yang lebih tinggi daripada limbah kepala udang, namun limbah kepala udang memiliki kadar air lebih kecil dibandingkan dengan ikan segar. Kemungkinan kadar air yang lebih kecil tersebut menyebabkan umpan limbah kepala udang jika direndam lebih lama akan susah larut kandungan kimianya di perairan dibandingkan ikan segar. Hal ini diperkuat oleh Winarno (1992), yang menyatakan bahwa kandungan air yang lebih banyak inilah yang menjadikan umpan ikan segar jika direndam lebih lama waktu pada perairan kandungan kimianya lebih cepat menyebar, hal ini dikarenakan air dapat berfungsi sebagai bahan yang dapat mendispersikan berbagai senyawa yang ada dalam suatu bahan, dan sebagai pelarut pada beberapa bahan lainnya. Menurut Muzzarelli dan Joles (2000) dalam Wowor et al. (2015), limbah udang mengandung protein kasar sekitar 25-40\%, kalsium karbonat 45-50\% dan kitin 15-20\%. Selain itu, limbah udang sendiri mengandung karotinoid berupa astaxantin yang merupakan pro vitamin A untuk pembentukan warna kulit. Berdasarkan kandungan tersebut, maka limbah udang dapat digunakan sebagai pakan atau umpan.

Data dua jenis umpan yang berbeda di atas selanjutnya akan dianalisis menggunakan Uji-t untuk membuktikan hipotesis bahwa terdapat pengaruh umpan berbeda terhadap hasil tangkapan Rajungan (Portunus pelagicus). Nilai Sig. sebesar 0,538. Nilai tersebut lebih besar dari nilai Sig. $\alpha 0,05$. Oleh karena itu sebagaimana dasar pengambilan uji-t, apabila nilai Sig. > 0,05 maka dapat disimpulkan bahwa $\mathrm{H}_{0}$ diterima. Maka dapat disimpulkan bahwa tidak terdapat pengaruh umpan ikan segar dan umpan limbah kepala udang terhadap hasil tangkapan Rajungan (Portunus pelagicus) di Karimunjawa.

\section{Perbandingan Hasil Tangkapan Rajungan (Portunus pelagicus) Berdasarkan Waktu Immersing Berbeda}

Berdasarkan hasil penelitian yang dilakukan oleh peneliti sebanyak delapan kali ulangan dengan waktu immersing yang berbeda yaitu 6 jam dan 12 jam mendapatkan hasil tangkapan Rajungan (Portunus pelagicus). Perbandingan hasil tangkapan Rajungan (Portunus pelagicus) bubu lipat berdasarkan waktu immersing berbeda dapat dilihat pada Gambar 5.

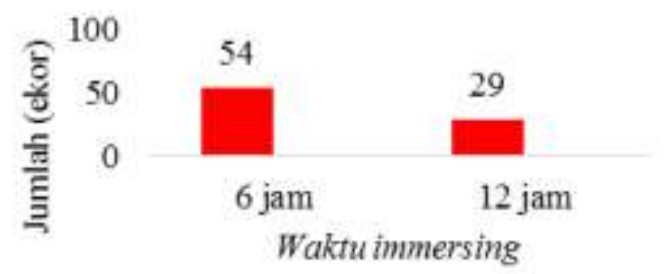

Gambar 5. Grafik Hasil Tangkapan Rajungan (Portunus pelagicus) Bubu Lipat Berdasarkan Waktu Immersing Berbeda

Berdasarkan Gambar 5, hasil tangkapan Rajungan (Portunus pelagicus) pada bubu lipat paling banyak terdapat pada bubu lipat yang direndam selama 6 jam yaitu 54 ekor. Hasil tangkapan Rajungan (Portunus pelagicus) pada bubu lipat yang direndam selama 12 jam yaitu 29 ekor. Jumlah hasil tangkapan utama dari perlakuan waktu immersing 6 jam lebih banyak dibandingkan waktu immersing 12 jam. Hal tersebut kemungkinan disebabkan oleh cuaca buruk yang terjadi setelah pengoperasian pada minggu pertama, sehingga mempengaruhi hasil tangkapan pada pengoperasian minggu selanjutnya. Hal tersebut diperkuat oleh Tiyoso (1979) dalam Pradenta et al. (2014), yang menyatakan bahwa fluktuasi hasil tangkapan dari alat tangkap jenis bubu terjadi karena migrasi dan perubahan harian, musiman, maupun tahunan dalam kelompok ikan, keragaman ukuran ikan dalam populasi, serta tepat tidaknya penentuan tempat pemasangan bubu, karena alat tangkap jenis ini bersifat pasif.

Data waktu immersing yang berbeda diatas selanjutnya akan dianalisis menggunakan uji-t untuk membuktikan hipotesis bahwa terdapat perbedaan hasil tangkapan antara waktu immersing 6 jam dan waktu immersing 12 jam. Nilai Sig. sebesar 0,512. Nilai tersebut lebih besar dari nilai Sig. $\alpha$ 0,05 . Oleh karena itu sebagaimana dasar pengambilan uji-t, apabila nilai Sig. > 0,05 maka dapat disimpulkan bahwa $\mathrm{H}_{0}$ diterima. Maka dapat disimpulkan bahwa tidak terdapat pengaruh waktu immersing 6 jam dan 12 jam terhadap hasil tangkapan Rajungan (Portunus pelagicus) di Karimunjawa.

\section{Pengaruh Umpan Berbeda Dan Waktu Immersing Terhadap Hasil Tangkapan Rajungan (Portunus pelagicus)}

Data hasil tangkapan Rajungan (Portunus pelagicus) yang telah dianalisis menggunakan uji-t membuktikan hipotesis bahwa tidak terdapat pengaruh umpan dan waktu immersing terhadap hasil tangkapan Rajungan (Portunus pelagicus). Untuk mengetahui interaksi kedua variabek tersebut maka digunakan grafik interaksi dari aplikasi SPSS 22.0. Adapun hasil analisa interaksi ini juga ditunjukan pada grafik estimated marginal yang disajikan pada Gambar 6 .

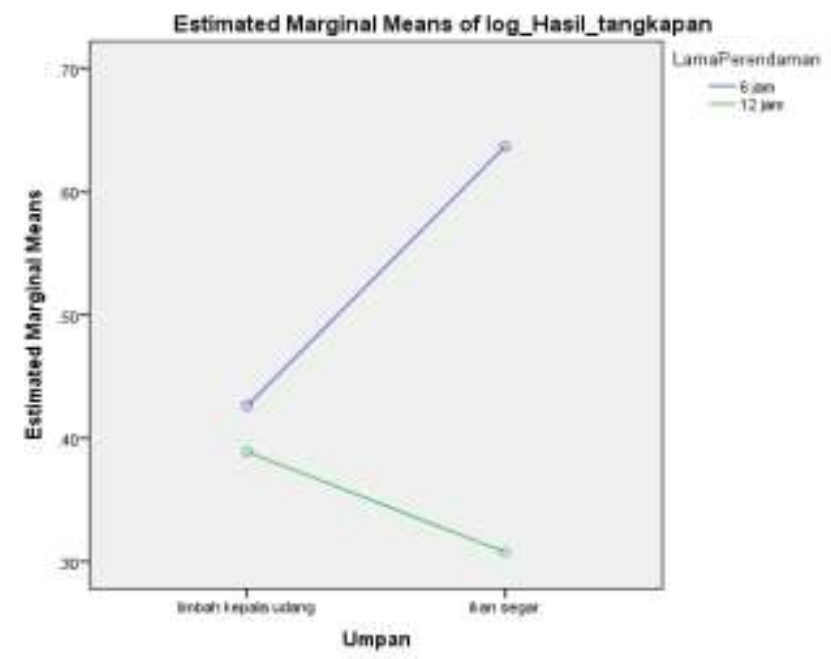

Gambar 6. Grafik Interaksi Umpan Berbeda dan Waktu Immersing Terhadap Hasil Tangkapan Rajungan (Portunus Pelagicus)

Berdasarkan Gambar 6, dapat diketahui bahwa tidak terdapat perpotongan garis dari perlakuan umpan dan waktu immersing berbeda terhadap hasil tangkapan Rajungan (Portunus pelagicus), yang memberikan kesimpulan tidak ada interaksi antara kedua perlakuan tersebut. Umpan dan waktu immersing yang berbeda dalam penelitian ini tidak saling mempengaruhi hasil tangkapan Rajungan (Portunus pelagicus). Sehingga dapat disimpulkan bahwa Rajungan (Portunus pelagicus) dapat tertangkap pada alat tangkap bubu

(c) Copyright by Saintek Perikanan (Indonesian Journal of Fisheries Science and Technology), ISSN : 1858-4748 
lipat dengan umpan limbah kepala udang maupun ikan segar, serta dengan waktu immersing selama 6 jam dan 12 jam.

Waktu immersing tidak berkaitan dengan umpan yang berbeda pada bubu lipat yang digunakan. Hal ini dibuktikan dengan hasil analisis yang memberikan hasil kesimpulan tidak terdapat hubungan antara umpan yang berbeda dengan waktu immersing berbeda. Menurut Widiharih (2007), ada tidaknya pengaruh interaksi dapat diteliti dari perilaku respon suatu faktor pada berbagai kondisi faktor lain. Jika respon suatu respon berubah pola dari kondisi tertentu ke kondisi lain untuk faktor yang lain maka kedua faktor dikatakan berinteraksi. Sedangkan bila respon dari suatu faktor tidak berubah pada berbagai kondisi faktor yang lain dapat dikatakan kedua faktor tidak berinteraksi.

\section{KESIMPULAN}

Kesimpulan yang dapat diambil dari Penelitian yang telah dilakukan adalah sebagai berikut:

1. Hasil tangkapan Rajungan (Portunus pelagicus) pada bubu lipat dengan umpan ikan segar lebih banyak. Hal tersebut dikarenakan ikan segar memiliki kandungan protein $57,23 \%$ yang lebih tinggi daripada limbah kepala udang;

2. Hasil tangkapan Rajungan (Portunus pelagicus) pada bubu lipat dengan waktu immersing 6 jam lebih banyak. Hal tersebut dikarenakan kadar air pada ikan segar 74,79\% dan limbah kepala udang 73,43\%, sehingga apabila direndam dengan waktu immersing lebih cepat maka respon makan rajungan juga semakin cepat; dan

3. Tidak terdapat interaksi antara umpan ikan segar dan umpan limbah kepala udang serta waktu immersing selama 6 jam dan 12 jam terhadap hasil tangkapan Rajungan (Portunus pelagicus) pada penangkapan bubu lipat di Karimunjawa.

\section{UCAPAN TERIMA KASIH}

Penulis mengucapkan terima kasih kepada PPP Karimunjawa dan Bapak Ahmad yang telah membantu dan mengarahkan dalam pengambilan data di lapangan.

\section{DAFTAR PUSTAKA}

Arios, A. H., Suradi W. S., dan Anhar S. 2013. Hasil Tangkapan Rajungan (Portunus pelagicus) dengan Menggunakan Alat Tangkap Bubu Lipat yang Didaratkan di TPI Tanjung Sari Kabupaten Rembang. Journal of management of aquatic resources, 2 (2): $243-248$.

Monintja, D.R. dan Martasuganda. 1991. Diktat Kuliah Teknologi Pemanfaatan Sumberdaya Hayati Laut II (tidak dipublikasikan). Institut Pertanian Bogor, Proyek Peningkatan Perguruan Tinggi Institut Pertanian Bogor, Bogor.

Pangalila, F. P. T. dan Ivor L.L. 2016. Perbandingan Hasil Tangkapan Rajungan pada Alat Tangkap Bubu Kerucut dengan Umpan Berbeda. Jurnal Ilmu dan Teknologi Perikanan Tangkap, 2 (4) : 154-158.

Pradenta, G. B., Pramonowibowo, dan Asriyanto. 2014. Perbandingan Hasil Tangkapan Bubu Lipat dengan Bubu Lipat Modifikasi Terhadap Hasil Tangkapan Kepiting Bakau (Scylla serrate) di Ekosistem Mangrove Sayung Demak. Journal of Fisheries Resources Utilization Management and Technology, 3 (2) : $37-45$.

Subani, W., dan Barus. 1989. Alat Penangkapan Ikan dan Udang Laut di Indonesia. Balai Penelitian Perikanan Laut Badan Penelitian dan Pengembangan Pertanian. Departemen Pertanian, Jakarta.

Wang, J. H., Shara F., dan Yonat S. 2010. Developing Visual Deterrents to Reduce Sea Turtle Bycatch in Gill Net Fisheries. Marine Ecology Progress Series, 408 : 241250. 10.1098/rsbl.2013.0383

Widiharih, Tatik. 2007. Buku Ajar Perancangan Percobaan. Program Studi Statistika, Jurusan Matematika, Fakultas Matematika dan Ilmu Pengetahuan Alam. Universitas Diponegoro. Semarang.

Widowati, N., Ririn I., dan Adi S. 2015. Efektivitas Umpan yang Berbeda pada Bubu Lipat untuk Penangkapan Rajungan yang Berbasis di Pelabuhan Perikanan Nuasantara Karangantu. Jurnal Perikanan dan Kelautan, 5 (2) : 25 - 33.

Winarno, F. G. 1992. Kimia Pangan dan Gizi. PT. Gramedia Pustaka Utama : Jakarta.

Wowor, A. R. Y., Bagau B., Untu L., dan Liwe H. 2015. Kandungan Protein Kasar, Kalsium, dan Fosfor Tepung Limbah Udang Sebagai Bahan Pakan yang Diolah dengan Asam Asetat $\left(\mathrm{CH}_{3} \mathrm{COOH}\right)$. Jurnal Zootek, 35 (1) : 1-9. 